\title{
Digital Printing Applications in Textile and Printing Industry of Turkiye
}

\author{
Sevim Yilmaz, Gulderen Cavus
}

\begin{abstract}
Digital printing method can be applied to fabric, paper ore ceramic, and is useful for many sectors, from fashion to marketing to interior design. Digital printing machines producers, have developed systems that will be an alternative to offset and other printing techniques and offer high quality, brighter and more colour possibilities at the desired speed, on the desired material and are more cost-effective.

The big ore middle sized Turkiye's textile and press companies are pursuing digital machine industry developments and are using final technologies of them on production.

In this study the prevalence of digital printing methods used in textile and printing industries of Turkiye were investigated and compared.
\end{abstract}

Index Terms - Digital printing, Textile industry, Press industry.

\section{INTRODUCTION}

The printing technique, based on the technique of transferring coloured ink drops on the fabric with special electrical signals, and where unlimited pattern length and unlimited colour combinations can be obtained is called digital printing technique.

Thanks to modern fabric printing techniques, today it's possible to produce limited quantities of textile products cheaply and quickly. Photos, colours and designs can be transferred to various materials without any particular creative or production constraint [1].

According to Rıza Başoğlu, the chairman of the board of directors of Lidya Group, which has an important place in the printing sector in Turkey, developments in the digital printed packaging sector are as follows: "Product variety and customer-oriented product structuring are improving the packaging industry. Corrugated cardboard plays an important role in developing the packaging sector. The reasons such as the fact that digital printing creates additional customers, provides customized version solutions, provides investment opportunities in the direction of development, shortening of preparation time and responding to urgent orders, extend the rapid development of the digital printing in the packaging sector.

Thus, the packaging industry with this facility are said to have reached a volume of 20 billion dollars in Turkey" [2].

Digital printing machines which could not find the place in the printing sector because of the fact that their costs were high and their quality was low in the years starting to be used became the attraction center of the sector by making progress in recent years [3].

Sevim Yilmaz, Pamukkale University, Denizli Technical Vocational School of Higher Education, Design Department, Denizli, TURKIYE

Gulderen Cavus, Pamukkale University, Denizli Technical Vocational School of Higher Education, Design Department, Denizli, TURKIYE

\section{DIGITAL PRINTING TECHNOLOGIES USED IN TEXTILE AND PAPER PRINTING}

Generally, Digital Printing Techniques: These Methods are known as NIP (non-impact printing) i.e. (non-contact printing) and have the following types:

1- Electro photographic and electrographic systems: The majority of office photocopiers and the basic technique of laser printers are included in this group.

2- Electro sensitive system: Some substances change by electric current. It is applied in devices with more small pressure areas. For example, the printer table calculator.

3- Magneto graphic systems: As with electrostatic systems, image is obtained with toner.

4- Inkjet systems: The ink is sprayed drop by drop and image is obtained.

5- Thermography systems: Image is provided by heat. For this purpose, coloured sensitized tapes or coated material is used. The application area is slow colour printers and digital colour photocopiers.

Although when digital printing is said only large size internal and external pressures come to mind, all printed materials can be produced with this printing technique. Works printed on paper, such as business cards, brochures, banners, labels, books, files, folders, notebooks, calendar, presentation, activity reports can also be produced with digital printing technology.

The printing technique, based on the technique of transferring coloured ink drops on the fabric with special electrical signals, and where unlimited pattern length and unlimited colour combinations can be obtained is called digital printing technique.

\section{A. Types of Outdoor Printing by Digital Printing.}

1- Canvas Print: Advertising works on buildings are included in this group.

2- Vinyl printing on signboard: Advertising banners adhered on the signboard.

3- Application on vehicle: Digital printing is done on foil. Piece-by-piece work is covered on vehicle by heat. A good coating is provided on the vehicle by heat.

4- Roadside advertisements: It is printed on glossy or $1^{\text {st }}$ grade paper with digital printing.

5- Three-dimensional billboards: Graphics are printed on vinyl or foil with solvent-based ink.

6- Floor graphics: Printing is made using friction-resistant solvent-based ink. Lamination is done against friction with lamination material (Floor Graphic).

7- Mega light medium refuge advertising billboards: The graphic is printed on a semi-opaque material called trans. 
8- Creative facade cladding prints: Vinyl-based graphics are printed with solvent-based ink. Advertising with this type of print are hang to the outside of the store and shopping centers. 9- Store facade applications: Work of the desired size is printed according to the machine size. It is combined with lamination.

10- Billboards: Desired graphics are printed on the $1^{\text {st }}$ grade paper of various weights.

11- Posters: It is printed on glossy paper, linoleum, fabric or vinyl with solvent based ink.

12- Cloth banners: The graphic is printed on the fabric of the desired size. Like flag prints.

\section{B. Interior (In Door) Printing:}

1- In-window applications: The applications are pasted into the showcase.

2- Artistic prints: Prints which give results like picture or painting on toile and canvas.

3-Stand system creation: The work is divided into pieces according to stand shape and adhered to the stand.

4- Glass graphics: Printing on a perforated material for glass surfaces. Printing on the one way vision material. From the inside out, outside looks. It does not appear when viewed from the outside, only the image appears.

5- Billboards for market, business center and places : There is no need for lamination since it will not be exposed to outside air.

6- Decoration applications and illuminated prints: The prepared graphic is printed on a semi-transparent material called "duratrans".

7- Applications on canvas: Printing material is made of canvas. It has an elastic structure after it is finished and it can be mounted anywhere.

8- Photo prints: Photo prints on photo paper.

9- Illuminated Advertising Panels: Backlight is printed on "duratrans" material. Used in the illuminated interior signs of the restaurants.

\section{Digital Printing Technologies Used in Paper Printing}

The image is transferred on paper by two methods. - Ink-jet systems: The ink is sprayed dropwise and the image is obtained. Cartridges filled with liquid ink are used for printing. Special writing tips adjust the amount of ink required and allow spraying onto paper. These tips consist of a series of micro-tube parts that work through electronic signals [4]. Ink-jet printers have many different technologies, but depending on the technology they are used for small or large size printing. It can print on many materials as well as paper.

Picture 1. Billboards Applications [5].

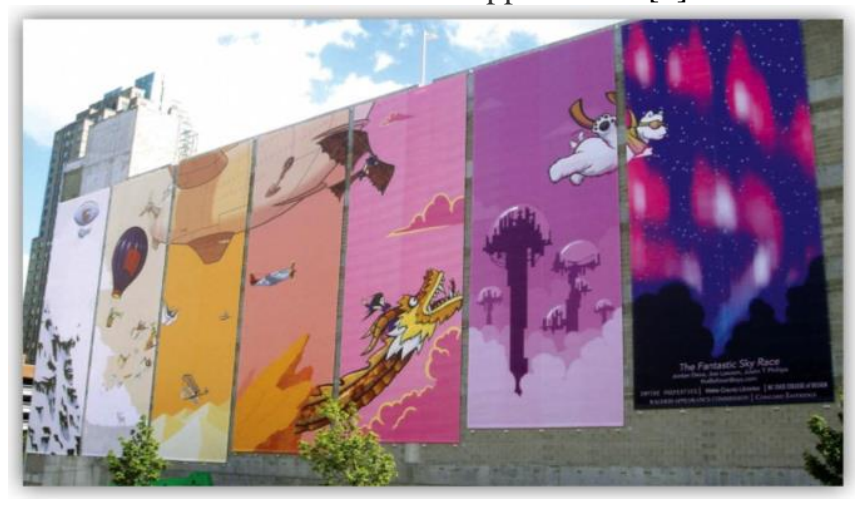

- Laser Systems: The image is obtained with toner. The particles of toner powders are transferred to the paper by heating in the furnaces of the printer to 180 - 200 degrees. A powder fraction in the toner powder ranges from 8 to 10 micrometers [6]

Laser printing technology can produce the highest resolution and the highest quality printing. Silent operation, quality and speed of laser printers are important features. From these printers, printing quality can be output. Although the devices are relatively expensive, they are preferred because they are fast, reliable and economical. Laser printers are considered economic printers because of the cheaper and longer-lasting toner. [7]

\section{Digital Printing Technology Applications on Textile Surfaces}

Digital printing by words means printing which is done in computer-aided digital media. To be a little more explanatory, the development of sensitive digital media, which has been accelerated in recent years, to be written on cloth, textile, nylon surfaces with the support of multiple providers. Nowadays, fabric and textile companies are using digital printing. Thus, there is no need to prepare templates or patterns to be prepared for days for the samples. One of the important issues in direct digital printing on fabric is the pre-preparation of the fabric to be printed and the post-printing fixation.

\section{1- Fabric preparation}

Depending on the fiber property of the fabric, dyes with suitable affinity are used (such as reactive, acid, disperse); different types of applications are applied according to the fabric content for dye types to be used. With these pre-treatments, the fabric is prepared before printing and the best quality of printing are provided on the fabric in order to prevent the dye from spilling or spreading. In this system, there is no need to constantly monitor the printing and make sure that there is no trace in the print.

2- Finishing Processes

The persistence of the printing after digital printing depends on the proper setting of the fixing process for fabric dyeing element fixation. After fixing, washing and rinsing, drying and adjusting the most desired quality properties are provided in fabrics.

\section{DIGITAL PRINTING MACHINES IN THE TURKIYE MARKET}

When we visited the some of popular textile printing and press companies in Istanbul, Bursa, Izmir and Denizli we were surprised to see the newly developed technologies on production process.

In this study, digital printing machines have been investigated in two groups according to the printing material to be used as paper and fabric.

\section{A. Digital Printing Machines for Textile Printing}

On digital presses, all machine functions are controlled by a PC server and monitored by the LCD PC screen. Digital printing and digital textile printing, each of which is a global brand Mutoh, Mimaki, La Meccanica machine manufacturers such as supplying products, technical service of machines; the machine used in the supply of varieties of paint and digitally prepared with the software, they developed an application to 
the fabric you want to apply instantly. AIT is also a manufacturer of Miracle textile software. Since 1996, AIT has been providing software, hardware and technical support on electronic design, pattern design, digital sample, and short printing. Mette Textile Turkey, as of 2008, sister company Endotek Printing Technology Ltd. is another company in the textile market regarding digital textile (fabric) printing machines, inks, and other auxiliary materials [8].

Picture 2. Digital Printing Machine for Textile

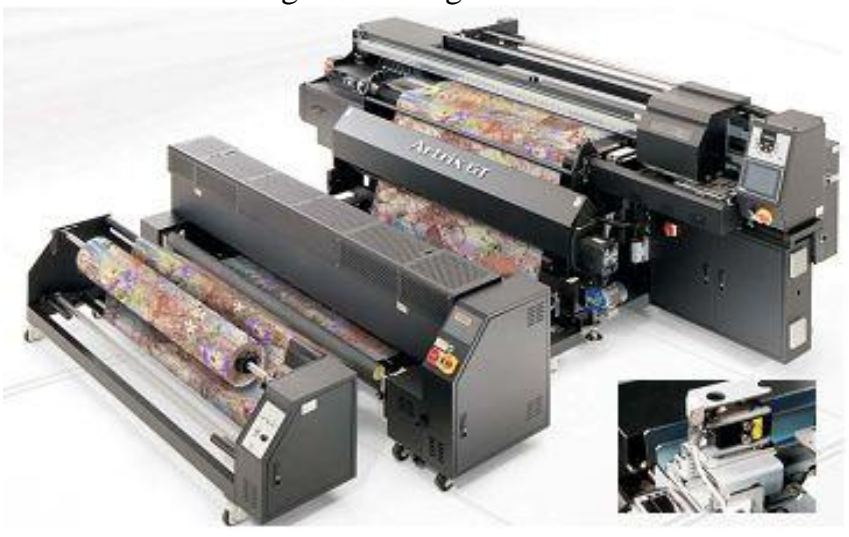

Table 1. The Technical Features of Major Industrial Digital Textile Printing Machinery

\begin{tabular}{|c|c|c|c|c|}
\hline Brand & $\begin{array}{l}\text { D-Gen, } \\
\text { Artrix GT }\end{array}$ & $\begin{array}{l}\text { Konica } \\
\text { Minolta, } \\
\text { Nassenger } \\
\text { VII }\end{array}$ & $\begin{array}{l}\text { ATEXCO, } \\
\text { Vega }\end{array}$ & $\begin{array}{l}\text { Mimaki } \\
\text { TX3 - } \\
1600\end{array}$ \\
\hline \multicolumn{5}{|l|}{$\begin{array}{l}\text { Dimensions } \\
\text { (most-size) }\end{array}$} \\
\hline $\begin{array}{l}\text { Production } \\
\text { Speed }\end{array}$ & $100 \mathrm{~m} / \mathrm{h}$ & $2,17 \mathrm{~m} / \mathrm{h}$ & $140 \mathrm{~m}^{2} / \mathrm{h}$ & \\
\hline $\begin{array}{l}\text { Ink count } \\
\text { and weight }\end{array}$ & $\begin{array}{l}\text { cartridge } \\
\text { system, } 8 \\
\text { coloured, } \\
2 \quad \text { tt / } \\
\text { colour } \\
\text { paint } \\
\text { tank } \\
\end{array}$ & $\begin{array}{l}\text { The capacity } \\
\text { of the system } \\
\text { is } 10 \mathrm{~kg} \text { per } \\
\text { paint }\end{array}$ & 8 coloured & $\begin{array}{l}2 \quad \text { lt } / \\
\text { colour } \\
\text { paint } \\
\text { tank }\end{array}$ \\
\hline $\begin{array}{l}\text { Printing } \\
\text { Method }\end{array}$ & Inkjet & Inkjet & Inkjet & Inkjet \\
\hline $\begin{array}{l}\text { Number of } \\
\text { Heads }\end{array}$ & 16 & 24 & 16 & \\
\hline $\begin{array}{l}\text { Number of } \\
\text { holes on the } \\
\text { plate }\end{array}$ & 508 & & 256 & \\
\hline $\begin{array}{l}\text { Adhesive } \\
\text { banded } \\
\text { band }\end{array}$ & has & has & - & - \\
\hline $\begin{array}{l}\text { Align fabric } \\
\text { edges with } \\
\text { photocell }\end{array}$ & - & has & has & - \\
\hline $\begin{array}{l}\text { Printed } \\
\text { material } \\
\text { feature }\end{array}$ & $\begin{array}{l}\text { Fabrics } \\
\text { of } \\
\text { different } \\
\text { thickness }\end{array}$ & $\begin{array}{ll}\text { Fabrics of } \\
\text { different } \\
\text { thickness }\end{array}$ & $\begin{array}{ll}\text { Fabrics of } \\
\text { different } \\
\text { thickness }\end{array}$ & $\begin{array}{l}\text { Printing } \\
\text { on } \\
\text { flexible } \\
\text { and fine } \\
\text { materials } \\
\text { (such as } \\
\text { tulle) }\end{array}$ \\
\hline $\begin{array}{l}\text { Drying } \\
\text { System }\end{array}$ & & $\begin{array}{l}\text { combination } \\
\text { of both hot } \\
\text { air-flow and } \\
\text { IR lamps }\end{array}$ & $\begin{array}{l}\text { Low energy } \\
\text { and water } \\
\text { consumption } \\
\text { infra-red } \\
\text { drying }\end{array}$ & \\
\hline $\begin{array}{l}\text { Laser } \\
\text { sensor for } \\
\text { nozzle hole } \\
\text { obstruction }\end{array}$ & & has & & has \\
\hline
\end{tabular}

BTC - Information Technologies and Consultancy Services Ltd. have been serving the textile sector for almost 25 years. It is known that the manufacturers of digital printing machines, where BTC distributes, are DuPont Artistri, Konica Minolta, Monna Lisa, Reggiani and Rimslow, and Kornit in piece printing. It is the Rimslow brand that manufactures machinery for fixation and has many users worldwide; especially for digital printing machines, fabric pre-preparation, steam fixing, and washing machines provide practical solutions to the user [8].

On the Table 1. are shown the major industrial digital textile printing machinery brands and their features.

\section{B. Digital Press Machines Used in Paper Printing}

EFI Nozomi C18000: EFI, an Eight Must See'Ems award-winning company, recently presented the EFI Nozami C 18000 single-pass corrugated cardboard printing machine, which received the Must See'Ems award in 2016, as a powerful machine for the corrugated packaging industry.

EFI VUTEk HS125 Pro: It can print with high speed on flexible or rigid substrates with thickness up to 126.5 inches $(3.2 \mathrm{~m})$ and 2 inches $(5.08 \mathrm{~cm})$. Offers white and clear ink choices. It offers the fastest and lowest total cost of printing banners, bus stops, double sided banners, exhibition, graphics, posters etc.(https://www.efi.com/products/inkjet-printing-and-proofi ng/vutek-superwide-printers/high-volume/versatile-hybrid-fl atbed-roll-fed/efi-vutek-hs125-pro/overview/).

HP Indigo 50000: It can print on almost any type of paper with oversized duplex roll fed used for high-coverage jobs. This press is optimized for high-quality, high-volume applications such as photo-books, cards, magazines, publishing and more [9] .

Konica Minolta Accurio Jet KM-1: Konica Minolta's original patented font edge processing technology enables the realization of excellent text quality with sharpness and legibility even for small font sizes. No exclusive paper types are required. Since it does not require the pre-processing as pre-coating, it is capable of handling a wide range of basic materials, including ordinary offset printing

paper. It can print on texture paper, a task that presents difficulties with offset or electro-photographic printing systems [10].

RICOH Pro VC60000: Sophisticated variable data printing capabilities allow you to print large quantities of brochures and marketing collaterals, direct mail, books, transaction documents and more with fully personalized images and texts [11].

Mimaki JFX200-2513: A choice of inks, including white and clear, offers unlimited creative opportunities, with the capability to print to a wide range of materials. Although it can print on all types of surfaces, the ink adhesion may differ according to the material. The range of possible applications is practically limitless [12].

Durst Delta 2500 HS: Variable, versatile, adjustable and configurable machine system, individually tailored to the needs of customers. It is on the reliable industry standard in the field of corrugated packaging and screen printing [13]. Above one Picture 3. are shown some digital printing applications on paper done by Durst Delta $2500 \mathrm{HS}$. 
Picture 3. Digital Printing Applications on Paper [13]
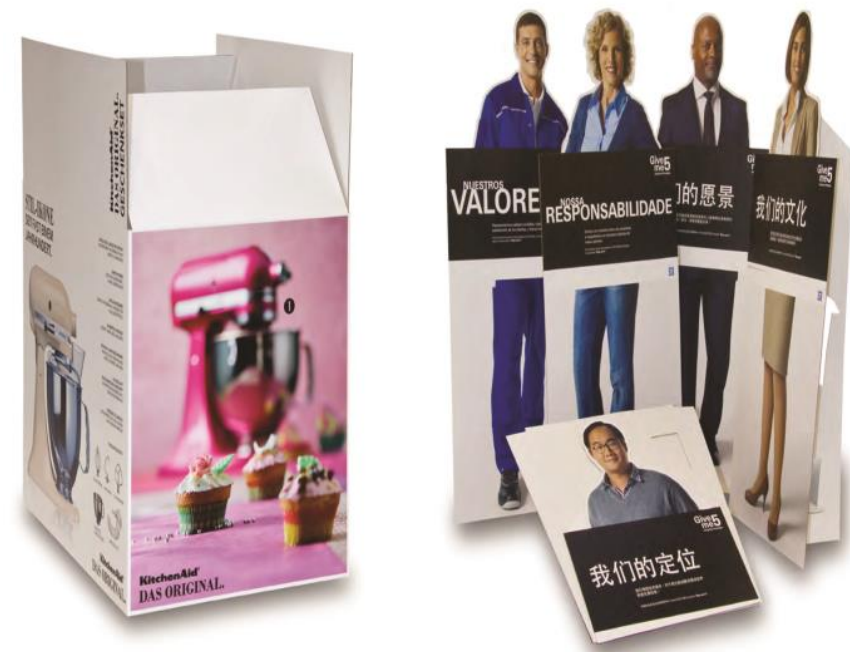

Table 2. The Technical Features of Some Brands For Digital Press Machines Used in Paper Printing

\begin{tabular}{|c|c|c|c|}
\hline Brand & $\begin{array}{ll}\text { HP } & \text { Indigo } \\
\mathbf{5 0 0 0 0} & \end{array}$ & $\begin{array}{l}\text { KONIKA } \\
\text { MINOLTA } \\
\text { KM-1 }\end{array}$ & $\begin{array}{ll}\mathrm{OH} & \text { Pro } \\
60000 & \end{array}$ \\
\hline $\begin{array}{c}\text { Dimensions } \\
\text { (most-size) }\end{array}$ & E: $70 \mathrm{~cm}$ B: roll & $58,5 \mathrm{~cm} \times 75 \mathrm{~cm}$ & $\begin{array}{l}52 \mathrm{~cm} \times 137 \\
\mathrm{~cm}\end{array}$ \\
\hline Print Speed & $\begin{array}{l}42 \mathrm{~m}(760 \mathrm{p} .) \\
\text { Coloured }-142 \mathrm{~m} \\
(2.280 \text { pages }) ; \\
\text { Single colour / } \\
\text { Minutes }\end{array}$ & $\begin{array}{l}3000 \text { one side } \\
-1500 \text { Double } \\
\text { sides / hour }\end{array}$ & $\begin{array}{l}150 \text { meters } \\
\text { per minute }\end{array}$ \\
\hline Color Range & $\begin{array}{l}4(\mathrm{CMYK})+2 \\
\text { Pantone }+2 \\
\text { Pantone }\end{array}$ & 4 (CMYK) & 4 (CMYK) \\
\hline $\begin{array}{l}\text { Number of } \\
\text { Heads }\end{array}$ & $4,6,8$ & 4 & 4 \\
\hline $\begin{array}{l}\text { Printing } \\
\text { Method }\end{array}$ & Inkjet & Inkjet & Inkjet \\
\hline Ink Feature & $\begin{array}{l}\text { Pigment Based, } \\
\text { Gel }\end{array}$ & UV base & Pigment base \\
\hline Drying & $\begin{array}{l}\text { Due to the ink } \\
\text { feature, it dries } \\
\text { quickly. }\end{array}$ & UV & $\begin{array}{l}\text { Due to the } \\
\text { ink feature, it } \\
\text { dries } \\
\text { quickly. }\end{array}$ \\
\hline $\begin{array}{l}\text { Paper } \\
\text { Features }\end{array}$ & $\begin{array}{l}40-350 \mathrm{~g} / \mathrm{m}^{2} \text {; } \\
\text { (varies due to } \\
\text { the paper } \\
\text { thickness) } \\
\text { Thickness: } 70- \\
400 \mu \mathrm{m} \text { coated } \\
\text { ore uncoated } \\
\text { paper. }\end{array}$ & $\begin{array}{l}350 \mathrm{~g} / \mathrm{m}^{2} \text {, coated } \\
\text {, uncoated paper } \\
\text { ore plastic } \\
\text { material }\end{array}$ & $\begin{array}{l}\text { Maximum } \\
250 \quad \mathrm{~g} / \mathrm{m}^{2} ; \\
\text { coated, } \\
\text { uncoated } \\
\text { plain ore } \\
\text { recycled } \\
\text { paper }\end{array}$ \\
\hline Advantage & $\begin{array}{lr}\text { For } & \text { fast, } \\
\text { low-volume } \\
\text { jobs, } & \text { 8-color } \\
\text { printing, bright } \\
\text { colours, allows } \\
\text { printing } & \text { of } \\
\text { variable } & \text { data } \\
\text { related } & \text { to } \\
\text { customer } & \\
\text { relations. } & \end{array}$ & $\begin{array}{l}\text { For fast, } \\
\text { low-volume jobs, } \\
\text { bright colours } \\
\text { allow the printing } \\
\text { of variable data } \\
\text { related to } \\
\text { customer } \\
\text { relations, the } \\
\text { same as the cost } \\
\text { of printing. }\end{array}$ & $\begin{array}{l}\text { For fast, } \\
\text { low-volume } \\
\text { jobs, bright } \\
\text { colours, } \\
\text { customized } \\
\text { prints, } \\
\text { variable data } \\
\text { printing are } \\
\text { possible. }\end{array}$ \\
\hline $\begin{array}{l}\text { Disadvantag } \\
\text { e }\end{array}$ & $\begin{array}{l}\text { Consumables } \\
\text { price is high }\end{array}$ & $\begin{array}{l}\text { Consumables } \\
\text { price is high }\end{array}$ & $\begin{array}{l}\text { Consumable } \\
\mathrm{s} \text { price is } \\
\mathrm{high}\end{array}$ \\
\hline Brand & $\begin{array}{l}\text { Durst } \\
2500 \text { HS }\end{array}$ & $\begin{array}{l}\text { Mimaki } \\
\text { JFX200-2513 }\end{array}$ & $\begin{array}{l}\text { EFI } \\
\text { VUTEK } \\
\text { HS125 Pro }\end{array}$ \\
\hline $\begin{array}{c}\text { Dimensions } \\
\text { (most-size) }\end{array}$ & $\begin{array}{l}248,92 \mathrm{~cm} \times 320 \\
\mathrm{~cm}\end{array}$ & $2500 \times 1300 \mathrm{~cm}$ & $\begin{array}{l}221 \mathrm{~cm} \mathrm{x} 732 \\
\mathrm{~cm}\end{array}$ \\
\hline Print Speed & 190 board / hour & $25 \mathrm{~m}^{2} /$ hour & $\begin{array}{l}125 \text { board / } \\
\text { hour }\end{array}$ \\
\hline
\end{tabular}

\begin{tabular}{|c|c|c|c|}
\hline Color Range & $\begin{array}{l}4(\mathrm{CMYK})+2 \\
\text { Pantone }+2 \\
\text { Pantone }\end{array}$ & $\begin{array}{l}4(\mathrm{CMYK})+2 \\
\text { Pantone + } \\
\text { Pantone }\end{array}$ & 4 (CMYK) \\
\hline $\begin{array}{l}\text { Number of } \\
\text { Heads }\end{array}$ & $4,6,8$ & $4,6,8$ & 4 \\
\hline $\begin{array}{l}\text { Printing } \\
\text { Method }\end{array}$ & Inkjet & Inkjet & Inkjet \\
\hline Ink Feature & UV base & UV base & $\begin{array}{l}\text { Ultra Drop } \\
\text { (Latex) } \\
\end{array}$ \\
\hline Drying & UV - LED & UV - LED & UV - LED \\
\hline $\begin{array}{l}\text { Paper } \\
\text { Feature }\end{array}$ & $\begin{array}{l}\text { Variety of } \\
\text { uncoated and } \\
\text { coated material, } \\
\text { also printed } \\
\text { paper surfaces, } \\
\text { up to } 5 \mathrm{~cm} \\
\text { thickness }\end{array}$ & $\begin{array}{l}\text { Variety of } \\
\text { uncoated and } \\
\text { coated material, } \\
\text { also printed paper } \\
\text { surfaces, up to } 5 \\
\text { cm thickness }\end{array}$ & $\begin{array}{l}\text { Variety of } \\
\text { uncoated and } \\
\text { coated } \\
\text { material, also } \\
\text { on structured } \\
\text { paper } \\
\text { surfaces, } \\
\text { Corrugated } \\
\text { cardboard, } \\
\text { up to } 5 \mathrm{~cm} \\
\text { thickness }\end{array}$ \\
\hline Advantages & $\begin{array}{l}8 \text { colour print, } \\
\text { bright colours } \\
\text { for fast, small } \\
\text { pieces of work }\end{array}$ & $\begin{array}{l}\text { For fast, small } \\
\text { pieces of work, } \\
\text { bright colours } \\
\text { match the cost of } \\
\text { printing }\end{array}$ & $\begin{array}{l}\text { Brilliant } \\
\text { colours for } \\
\text { fast, small } \\
\text { pieces of } \\
\text { work. Printer } \\
\text { cannot print } \\
\text { the thickness } \\
\text { of the } \\
\text { printing } \\
\text { press }\end{array}$ \\
\hline $\begin{array}{l}\text { Disadvantag } \\
\text { es }\end{array}$ & $\begin{array}{l}\text { UV - solvent } \\
\text { based inks affect } \\
\text { human health } \\
\text { due to the } \\
\text { outdoor. }\end{array}$ & $\begin{array}{l}\text { UV - solvent } \\
\text { based inks affect } \\
\text { human health due } \\
\text { to the outdoor. }\end{array}$ & $\begin{array}{l}\text { UV - solvent } \\
\text { based inks } \\
\text { affect human } \\
\text { health due to } \\
\text { the outdoor. }\end{array}$ \\
\hline
\end{tabular}

\section{CONCLUSION}

The big ore middle sized Turkiye's textile and press companies are pursuing digital machine industry developments and are using final technologies of them on production. That's why textile industry in the Turkiye is very competing and popular worldwide.

It is a fact that digital printing machines are developing very rapidly in almost every printing area. Digital printing arises from small-size office works by developing in the printing sector to the larger size printing machines, which can print on rolls of textile and paper with broad width and length , as well as printing can be pressed on all kinds of material and surfaces .

With the rapid development of computer technology and the increase in people's internet usage, the number of printed works on paper is decreased and the number of exclusive off-the-shelf works is increased. Offset printing and other printing systems were costly for low circulation works, while digital printing was expensive in printing large-scale works. Digital printing machine producers, have developed systems that will be an alternative to offset and other printing techniques and offer high quality, brighter and more colour possibilities at the desired speed, on the desired material and are more cost-effective.

In contrast with other printing systems, digital printing makes it possible to intervene immediately to errors, offers convenience because it does not occupy space in archiving and shortens time as it eliminates pattern in textile and paper printing sectors. As a result, it seems that digital printing systems will dominate other printing technologies in the printing sector in a short time. 


\section{REFERENCES}

[1] Cantavalle, S., April 11, 2018, Fabric Printing Techniques, Available: https://www.pixartprinting.co.uk/blog/fabric- printing-techniques

[2] http://www.printondemand.com.tr/canon-cutting-edge-etkinliginibasariylatamamladi/

[3] Y. Yavuz, Integration Of Digital Printing Technologies In Printing Sector, 5th International Printing Technologies Symposium, 04-05 November, 2016

[4]

Kaya, A., May 3, 2016. Available: https://www.tech-worm.com/murekkep-puskurtmeli-yazici-inkjet-ned ir/

[5] https://sdgmag.com/features/high-growth-soft-signage

[6] (http://www.tonergerikazanim.com/toner-nedir)

[7] Kaya, A., Februari 21, 2017. Available: https://www.tech-worm.com/lazer-yazici-nedir-lazer-yazici-yapisi-cal ismasi-nasildir

[8]

http://tekstilkutuphane.blogspot.com/2011/05/digital-basknn-tekstil-b askclgndaki.html)

[9]

https://www8.hp.com/us/en/commercial-printers/indigo-presses/5000 0.html

[10] https://bt.konicaminolta.in/accurio-jet-km-1/

[11]

https://www.ricoh-usa.com/en/products/commercial-industrial-printin $\mathrm{g} /$ continuous-feed/pro-vc60000)

[12]

http://www.mimaki.com.tr/products/uv-baski-makineleri/jfx200-2513

[13]

https://durstus.com/wp-content/uploads/2018/05/Durst-Delta-SeriesEN_USA.pdf 